\title{
MIGRANT YOUTH PUSH BACK. VIRTUAL FRIENDSHIPS AND EVERYDAY RESISTANCE IN THE DIGITAL SPHERE
}

\author{
JOVENS MIGRANTES EMPURRAM PARA TRÁS. AMIZADES \\ VIRTUAIS E RESISTÊNCIA COTIDIANA NA ESFERA DIGITAL
}

\author{
Anna De Fina*
}

\begin{abstract}
Resistance has proven to be a hard concept to define. Debates about resistance in the sociological and sociolinguistic literature cover many aspects: from the degree to which resistance can be seen as related to established social groups (see Rampton 1996), to the level of agentivity and intention that is required for an action to be regarded as resistant, to the type of social behavior that qualifies. Thus, while some see resistance as based on actions, others see it as based on cultural appropriation (Hall \& Jefferson 1976). In their comprehensive review of literature on the topic, Hollander \& Einwohner (2004) conclude that resistance can be seen as consisting of action and opposition. In this paper, I analyze resistance from the point of view of opposition to ideas, social situations, institutional actions and processes that result or may result in discrimination or stereotyping of specific social groups, as negotiated in the digital sphere by migrant and non-migrant youth belonging to a school-based community. Indeed, it has been argued (Chiluwa 2012, Chibuwe \& Ureke 2016) that digital environments constitute ideal arenas for the development of resistance thanks to their wide reach and their ability to mobilize people around common themes. However, much of the research in this area has targeted organized resistance fueled by political or ethnic groups. In this paper I argue that resistance is an emerging process that does not necessarily stem within political contexts or from open choice, but can develop within interactional exchanges focused on everyday life events. Thus, what I am interested in here is in how spontaneous acts and discourses of resistance emerge in the everyday exchanges of a diverse community that was not born around a particular social or political agenda. For this paper, I will examine exchanges that happen on the Facebook page of one of the members of the community. I will show how resistance takes many forms: from irony and jokes to the raising of serious topics, to the dissemination of information and through different discourse genres: from storytelling to the posting of pictures.
\end{abstract}

Keywords: migrants, digital communication, everyday resistance.

\section{RESUMO}

A resistência provou ser um conceito difícil de definir. Debates sobre resistência na literatura sociológica e sociolinguística abrangem muitos aspectos: desde o grau em que a resistência possa ser vista como relacionada a grupos sociais estabelecidos (ver Rampton 1996), até

\footnotetext{
* Georgetown University, Washington, D.C, Estados Unidos. definaa@georgetown.edu

Orcid: https://orcid.org/0000-0002-0007-972X
} 
o nível de agentatividade e intenção que é necessário para que uma ação seja considerada resistente, ao tipo de comportamento social que se qualifica. Assim, enquanto alguns veem a resistência como baseada em ações, outros a veem como baseada na apropriação cultural (Hall \& Jefferson 1976). Em sua revisão abrangente da literatura sobre o tema, Hollander \& Einwohner (2004) concluem que a resistência pode ser vista como constituída por ação e oposição. Neste artigo, analiso a resistência do ponto de vista da oposição a ideias, situações sociais, ações institucionais e processos que resultem ou possam resultar em discriminação ou estereótipo de grupos sociais específicos, conforme negociado na esfera digital por jovens migrantes e não migrantes pertencentes a uma comunidade escolar. De fato, tem sido argumentado (Chiluwa 2012, Chibuwe \& Ureke 2016) que os ambientes digitais constituem arenas ideais para o desenvolvimento da resistência graças ao seu amplo alcance e sua capacidade de mobilizar pessoas em torno de temas comuns. No entanto, grande parte das pesquisas nessa área tem como alvo a resistência organizada alimentada por grupos políticos ou étnicos. Neste artigo defendo que a resistência é um processo emergente que não necessariamente se baseia em contextos políticos ou de escolha aberta, mas pode se desenvolver dentro de trocas interacionais focadas em eventos cotidianos. Assim, o que me interessa aqui é como surgem atos espontâneos e discursos de resistência nas trocas cotidianas de uma comunidade diversificada que não nasceu em torno de uma determinada agenda social ou política. Para este artigo, examinarei as trocas que acontecem na página do Facebook de um dos membros da comunidade. Vou mostrar como a resistência toma muitas formas: da ironia e das piadas à criação de temas sérios, à disseminação de informações e através de diferentes gêneros de discurso: da narrativa à postagem de fotos.

Palavras-chave: migrantes, comunicação digital, resistência.

\section{INTRODUCTION}

In this paper I illustrate ways in which young migrants to Italy and their friends resist prejudice and stereotyping against them in mainstream discourses within interactions in a digital environment. I discuss how resistance should not necessarily be seen as something that comes consciously and deliberately from specific social agents, but should also be seen as an emerging process that takes place interactively and collaboratively. I will also show that acts of resistance may involve different discursive genres and strategies. The article is organized as follows: first I present different ways in which resistance has been defined and conceptualized in social theories and in sociolinguistics and anthropology. Then I introduce some theoretical/methodological premises of this work. I subsequently describe the study and analyze data coming from the Facebook wall of one young migrant to Palermo, Italy. The last section presents a discussion and conclusions. 


\section{CONCEPTUALIZING RESISTANCE}

A look at the entry for the word 'resistance' on the Merriam Webster dictionary is sufficient to illustrate some of the difficulties of defining the concept. Indeed, the dictionary describes the term as "an act or instance of resisting: OPPOSITION" and the verb 'to resist' as "to exert force in opposition", but also "to withstand the force or effect of" something. Already in these definitions one can appreciate contrasting conceptualizations of resistance as involving different degrees of initiative and activity. Indeed, exerting a force against something is not the same as withstanding something. The literature on resistance, which is wide as it spans across different disciplines - from psychology to sociology to anthropology to other social sciences - reflects these difficulties in conceptualizing this construct. Given the scope of this article, I will not try to be exhaustive, but I will review some basic ideas and developments in resistance studies.

The concept of resistance has been used to cover a range of different behaviors, from physical to institutional actions to psychological reactions, at a variety of scales, from the individual to the small group level to the level of organizations. In a comprehensive review of definitions and conceptualizations about resistance, Hollander \& Einwohner (2004) came to the conclusion that two elements were shared amongst diverse ways of approaching the concept and they were the ideas of action and opposition. Resistance is also generally seen as having a strong relationship with power in that, as famously stated by Foucault, "where there is power there is resistance" $(1978$, p. 95). Foucault discussed different kinds of resisting behaviors. For example, he talked about counter-conducts (2007, p. 215) that are not open oppositions to power, but rather refusals to comply with certain mandates that individuals may consider too costly to them. Besides pointing to the varied ways in which resistance is manifested, Foucault also posited - and this is something that post-modern resistance studies have assimilated - that exerting resistance does not necessarily mean being outside power mechanisms and institutions and that power and resistance are not antithetic forces but part of the same system. This conception is meant to reject romanticized visions of resistance as the action of uncontaminated and ideologically "pure" groups. In Urla \& Helepolei's words, Foucault

sought to show, for example, that the actors in gay, women's, and other liberation movements are not in a position of exteriority to the legal, medical, and sociological discourses of knowledge about them; rather, the logics of their resistance take shape within these (2014, 431). 
However, debates are still open on whether resistance is a conscious act or not and whether it implies active and agentive behavior, whether there can be resistance that goes unrecognized, whether covert action counts as resistance or not, and so forth. Resistance studies in anthropology and sociolinguistics have been influenced by views of resistance as constituted by everyday life actions and choices rather than being necessarily the fruit of organized action. In that sense the work of the sociologists from the Birmingham School in the late 1970's and 1980's, which focused on youth and subcultures emerging within the urban working class, was important to point to style choices and ritual as possible strategies of everyday resistance (Hall \& Jefferson, 1976). Similar to the idea of everyday resistance is de Certeau's concept of "everyday practices," (1984, p. xix), which include tactics that people deploy in order to "trick the system" or "get around" rules and impositions. These also do not amount to organized opposition. The idea of resistance that emerges from the work of these scholars allows for a comprehensive and open perspective in which opposition to power logics, or rules and behaviors imposed to social agents within unequal conditions can be expressed in many ways and at different levels. However, the Birmingham School scholars have been criticized because of a certain determinism in their views, since they tended to see specific ethnic or social groups as subjects of resistance par excellence. Rampton (1996) for example argued that contrary to what members of the Birmigham school thought, resistance should not be seen as deterministically connected to ethnic identity, or for that matter, to social identity in general. Today resistance is not seen as stemming from specific identity positions in society as identities themselves are not regarded as clearly determined in terms of established social categories but more as processes (see De Fina, 2011 and 2015 on this point). Recent studies of resistance also attempt to make sense of new social subjects and new forms of protest. For example, Judith Butler (2015) proposes that the mere act of assembling bodies in physical (such as in occupations or marches) or virtual spaces is an act of resistance. She talks about protest as a performance and of assembly as both a physical and a symbolic process of opposition to marginalization. What is important about this idea is that it widens the concept of resistance to the non-verbal realm and reaffirms the importance of everyday contexts. Butler identifies the victims of society, and therefore the prime agents of resistance, as those experiencing precarity. Although it can be said that by pointing to these 'prime agents,' Butler is in some way continuing the tradition of identifying specific groups as the privileged source of resistance, her concept of precarity as a unifying element still provides for a much wider and open ended categorization of people who may be entitled to resist as 
being precarious is a condition that cuts across classes, ethnicities, genders, and so forth.

In sum, it can then be said that post-modern conceptions of resistance distance themselves from deterministic approaches for which resistance is directly tied to the social position of agents as subordinated or marginalized and that they focus on the importance of "everyday" forms of opposition, non-compliance and so forth. However, much research in sociolinguistics and anthropology has concentrated on organized resistance. Urla \& Helepololei note for example that:

the nature of the object under study has shifted to be sure. If the 1980s was a time of concern with resistance with a small " $\mathrm{r}$ ", what is now garnering attention and stimulating conferences and special journal issues in anthropology and elsewhere are the newer tactics of self-conscious political mobilizing $(2014,432)$.

And indeed, research on resistance has focused on movements such as the Arab Spring (Elyachar \& Winegar, 2012), political movements in different countries (Idle \& Nunns, 2011; Lazar, 2017; Seloni \& Sarfati, 2017; Sinatora, 2019), antiausterity protests (Theodossopoulos, 2013), occupy movements (Hickel, 2012; Martin Rojo, 2014; Razsa \& Kurnik, 2012) or actions by specific ethnic groups (Mpofu, 2018; Chibuwe \& Ureke, 2016). Recently there has also been some investigation of how media discourses articulate resistance to anti-immigrant and antihumanitarian sentiments (Balabanova \& Trandafoiu, 2020).

One aspect that has come to light in resistance studies which have focused on organized movements has been the importance of digital contexts in the development of forms of resistance. Indeed, scholars such as Chiluwa (2012) and Chibuwe \& Ureke (2016) have argued that the space provided by online platforms allows minorities or marginalized groups the freedom to develop agentive responses to social issues and the networks and connections necessary to spread their messages and get in touch with people who share the same concerns. These ideas are also in tune with Butler's concept of assembly as described above as this author underscores the importance of virtual networking for creating solidarity and spurring action among people who suffer precarity.

Thus, the investigation of digital contexts has proven a fertile terrain for the study of acts of resistance. On the other hand, as evident from the review of literature above, in work on this topic there has been a certain neglect of spontaneous phenomena of resistance that emerge within contexts that are not political. The present article will try to fill this gap by focusing on an everyday context: Facebook exchanges among friends. In this article I regard resistance as an emergent process that develops within interactional exchanges among members 
of a group, that can be initiated by any participant and may generate or not an uptake by other participants. Resistance is here generally defined as encompassing opposition to ideas, social situations, institutional actions and processes that result or may result in discrimination or stereotyping of specific social groups. In our case the groups that are presented by participants as discriminated against are migrants, particularly African migrants, but sometimes also other minorities.

\section{MIGRANT YOUTH: IDENTITIES, COMMUNICATIVE RESOURCES AND RECIPROCITIES}

In this section, I review some of the theoretical methodological constructs that underlie the analysis presented here. In particular, I discuss how views of migrants and migration have been changing in the last two decades and how conceptions of communication among multilinguals have also evolved affecting the ways we regard interaction in superdiverse communities.

A changing view of migrants and transnational communities has been brought about largely thanks to scholars working within the frames of the linguistics of globalization and the superdiversity movement who, in turn, followed the lead of scholars of modernity such as Apparudai (1996) and Castells (2000). Appadurai for example pointed to the fact that due to globalization processes the scale, speed and intensity of human mobility and world interconnectedness that our societies are experiencing have reached unprecedented levels. The social economic conflicts that are continuously generated by increasing centralization of wealth and economic power, the redrawing of borders, the restrictive migratory policies of individual states and super-national entities and the insurgence of war and conflict in different parts of the globe all contribute to these unprecedented flows and determine a great deal of unpredictability in the trajectories of migrants and the complexity of their groupings. Superdiversity scholars such as the anthropologist Vertovec (2007) and sociolinguists such as Blommaert \& Rampton 2011 (but see also Arnaut et al. 2015; De Fina, Ikizoglu \& Wegner, 2017; Creese \& Blackledge, 2018) noted how migrant flows have profoundly changed with respect to the past not only because of the very diverse origins of the people comprising them, but also because of the fact that individual migrants do not become part of established communities. Their identities and communicative practices can no longer be understood in terms of ethnic origins or territorial belonging, not only because of increasing transnational connections across countries, but also because many migrants go through complex 
mobile trajectories that profoundly influence the ways they use linguistic resources and the kinds of social networks in which they participate.

Work on superdiversity and globalization has not only changed our view of migration, but also in general our way of approaching language and culture, since it has been focused on understanding how conditions for communication and cultural encounter have been transformed and how these transformations in turn affect the way we look at languages, identities and semiotic practices. Thus, there has also been a shift from languages as closed systems to communication understood as involving the deployment of a variety of linguistic resources from different named languages in conjunction with resources from a variety of other symbolic systems. These new understandings of languages as assemblages of resources underlie many of the constructs that have been proposed to capture on the one hand the fact that linguistic elements always work in conjunction with other kinds of semiotic resources in the achievement of communication among mobile and multilingual individuals, and on the other hand the hybrid character of linguistic resources themselves. Such conceptions underlie constructs such as translanguaging proposed by various authors (see Zhu Hua, Li Wei \& Lyons, 2017; Li Wei, 2018), metrolingualism (Pennycook \& Otsui, 2018) or "transidiomatic practices (Jacquemet 2019)." The latter refer to

the communicative practices of deterritorialized groups that interact using different languages and communicative codes simultaneously present in a range of communicative media, both local and distant" (p. 4).

Such views of language use as assembling different resources are of course particularly important to understand the type of communication which is the focus of the present study as it involves youth interacting virtually with other youth coming from different places and with a variety of language repertoires, who at the same time share many semiotic resources related to the way digital interaction is carried out among the peer group. Indeed, these youth use a variety of linguistic resources but they all employ emojis, memes, abbreviations and expressions taken from English, French and other named languages that have now become typical of the way they write and react to each other on Facebook.

Another premise of this article is that sociolinguists need to move more decidedly in the direction of understanding the dynamic and complex ways in which mobile and receiving individuals and communities and places affect each other. Sociolinguistic studies of migrant identities tend to focus on ingroups by looking at how identities are indexed through language practices and ideologies within specific communities or with an intracommunity lens. All of this contributes 
to a view of migration as a one-way street in the sense of something that basically impacts mainly the mobile people who are the protagonists of it. What I think is important instead is to understand migration as a phenomenon that impacts both societies and worlds in which migrants originated and the worlds in which they either stay or pass through and therefore that there needs to be greater focus on reciprocity (on this point see De Fina, Paternostro \& Amoruso 2020a). Migrants use technologies and other tools to build connections throughout their travels and these connections involve local people, who are at times also permanently changed by these encounters. From the perspective of this literature we could look at many of the communities or networks formed by migrants and local people as "third spaces" (Bhaba, 1994) with great potential for the creation of new meanings. We can also think about what migrants bring with them in terms of resources by recalling Papadoupoulos \& Tsianos (2013, p. 178-79) construct of "mobile commons", which they define as "the shared knowledge, affective cooperation, mutual support and care between migrants when they are on the road and when they arrive somewhere" but that crucially involve participation in different communities" and "an infrastructure of connectivity", that includes spaces of sociability and the use of digital technologies (2013, p. 191-192). In that sense the investigation of acts of resistance is part of a more general analysis of the ways in which communication happens among members of groupings that include migrants and local people.

\section{THE PROJECT}

As the data from this paper come from a project involving unaccompanied minors asylum (UMAS) seekers in Italy, I will first provide some information on this group. I will refer to statistics that present data for 2018. Indeed, migration flows to Italy were substantially reduced and reshaped during the ascent of the government coalition dominated by Matteo Salvini, the president of the right-wing party, Lega Nord, who served as Deputy Prime Minister and Minister of the Interior from 1 June 2018 to 5 September 2019. In this period migration patterns changed with respect to the time when the youth investigated here arrived in Italy.

Official counts of UMAS by the Italian Secretary of Labor (Ministero del Lavoro) indicate that in July 2018 the number of unaccompanied minors in Italy had reached 12,930. Most of these minors (92.4\%) were males and the great majority were between 15 and 17 years old. According to Colombo (2019), minors constituted 14.5 of total arrivals by sea and come from Albania, The Gambia, Egypt, 
Guinea, Ivory Coast, Eritrea, Nigeria, Mali and other countries. At least 42\% of these youth stay in Sicily.

As mentioned above, data for this paper come from a project which I have been conducting with UMAS who are, or have been students at an Italian language school in Palermo with colleagues from the University of Palermo (see De Fina, Paternostro \& Amoruso 2020a e b). The Language school in which our participants met has been instrumental in organizing language courses and other social and convivial activities for the minors who are students there. The main objective of the project is to study the identity formation and use of linguistic resources by students and former students within communities that include local members as well. Thus, in a first phase we looked at identity processes within storytelling practices in the community formed at the school by teachers and students and in our second phase we are following the Facebook profiles of four focal members, three migrants and one Italian. The project is ethnographic in nature. It includes observations, collection of artifacts, notetaking and interviews. In the case of the Facebook study we have adopted a virtual ethnography approach (Hine, 2015), based on long term observation of the FB posts and exchanges in order to get a sense of participants constructions about those interactions, followed by one or more interviews focusing on their use of the media and on their linguistic choices. Of the two researchers that participated in the project in the first phase besides me one, was a teacher who was in charge of courses taught to unaccompanied minors and the other one was a professor at the University who had frequent contact with minors in the program. Thus, our contacts among the students were made through the teachers' personal relations. The part of the study that concerns the Facebook postings was conducted by me and one of the two local researchers. We selected three minors whom he knew well and asked them if we could observe their FB walls and if they would accept us as FB friends in order to do that. We explained that our main objective was to look at language use in the posts. We received permission to do the study. As it happens often with social media, it was impossible for us to obtain permission by all the participants in the FB exchanges and for this reason I have anonymized all the data and transcribed all examples eliminating visuals. We have been observing the pages of our focal participants (three migrants from Africa and one Italian) starting in August 2018 and conducted interviews with them to both find out more about their life and clarify the meanings of specific instances of language use in the data. The relationships with the youth are based on reciprocal trust as they know the researchers and the school, but of course there are many differences in terms of class, age, nationality and life experiences that will have 
certainly played a role in the interviews, a topic that I have no space to develop here.

In this paper I will concentrate on the Facebook profile of one these participants, a young man from Guinea Conakry whom I will call Mohammed, who arrived on the Sicilian coast as asylum seeker and lives in Palermo. He has been living in Palermo for three years. His FB wall will be a point of observation of communication among members of his group of friends. Mohammed is no longer an asylum seeker, no longer a minor and no longer a student at the school even though he keeps close contacts with the people that he met there.

\section{VIRTUAL COMMUNITIES AND FACEBOOK COMMUNICATION}

The observations that we conducted on Mohammed's wall revealed that he communicated, and still does, on Facebook with a variety of individuals and groups. Following his posts and the posts in which he is tagged, it is possible to distinguish two main virtual communities that are brought together online and whose members may have different levels of offline interaction: one is constituted by relatives and close friends in Guinea and the other one is constituted mostly by friends that he made during his years as a student at the school of Italian. The latter are other migrants and local people, for example teachers or other young people whose activities were connected to the school. In this way Mohammed's use of Facebook is absolutely similar to that of other migrant youth who belong to this circle. The platform constitutes one of the tools through which they keep in touch with people from whom they are separated, a space for sociability with present friends, and a source of information and amusement.

Communication between Mohammed and these different communities is characterized in part by the patterns of language use, in part by the topics that are prevalent in the posts that he published and on which he is tagged. Indeed, posts addressed to the Guinean family and friends and in which he is tagged by them are usually in French, but also present translanguaging that involves African languages such as Susu or Fula. These posts are also often written in a digital transligua which uses memes, emojis, language mixtures, and abbreviations such as HBD for "Happy birthday" or tfrais for "tres frais" (cool). The distinctive topics here cover birthdays and national holidays and also political commentary on African affairs.

Communication with members of the local community revolves a great deal about events organized by the school or people in the school, social commentary on Italian affairs or questions related to migration. Both communities talk about 
everyday life and pop culture. However, in the case of the local community posts are often in Italian, but we also see translanguaging and the presence of the digital translingua that was described above. The generalized use of this digital translingua shows on the one hand that communication among young people follows similar patterns no matter what the country of origin is, but also that there is "context collapse" (see Vitak, 2012, p. 541), that is that members of separate networks may participate in exchanges together even if they usually do not communicate with each other. Typical examples of context collapse happen with birthdays where we find comments in different languages or in translanguaging. There is no space in this paper to discuss these issues in detail, but this brief introduction is aimed at providing some background for the analysis of resistance by members of these communities.

\section{ANALYSIS OF ACTS OF RESISTANCE}

I have defined resistance above as encompassing opposition to ideas, social situations, institutional actions and processes that result or could result in discrimination or stereotyping of specific social groups. I will also refer to "acts of resistance" as individual instances of resisting stereotypes, discrimination or aggression initiated directly or indirectly by any of the participants in the interactions analyzed. Acts of resistance often come with appeals to specific strategies of resistance. As we will see in the examples, an act of resistance can be the posting of a video demonstrating that information disseminated by the press about migrants is false, or the posting of an ironic comment that draws attention on some aspect of social reality that is regarded as discriminatory, for instance when participants make fun of antiimmigrant measures taken by the Italian government. In terms of the way acts of resistance are conveyed in this data, we find that they can be communicated through different kinds of posts in a variety of discursive genres: these include reflections on political events and figures, the advertising of events or initiatives by third parties taken in favor of migrants, ethical position posting and stories, i.e. the reporting of personal experiences. Reflections on political events and figures can be textual comments on political initiatives conducted by any social agent or group that affect or might affect migrants or on politicians whose discourses and work have an impact on their life and their rights (see example 1). These reflections can take the form of texts supporting or opposing specific measures or multimodal ensembles with video, photos, memes plus verbal comments, and so forth. Advertising of initiatives by third parties generally consists of the reposting of calls for participation, posters 
and information on cultural events, political mobilizations such as marches and petitions that are circulated by organizations or individuals who support either migrants and migration or other vulnerable subjects. Ethical positioning postings are usually conveyed through aphorisms or more generally expressions that aim at conveying adherence to a certain moral order. They often are presented in the form of photographs accompanied by brief texts that enounce a moral principle or a spiritual quality that the person posting particularly appreciates (see example 4). As we will see, texts and their embedding are important elements in the construction and uptake of these messages. We will also discuss how resistance can be conveyed indirectly (for example through ethical positioning posts) or emerge in comments to posts.

The analysis of acts of resistance in this paper is based on the examination of ways in which individuals position themselves in regards to events, people and discourses. Positioning was initially defined by Davies and Harré (1990: p. 48) as a discursive practice "whereby selves are located in conversations as observably and intersubjectively coherent participants in jointly produced story lines." What these authors were underlining was that identities are constructed in and through interaction among people rather than being just expressed or enunciated. Positioning analysis has developed more recently into one of the most important tools for analyzing identity construction interactively, particularly in the field of narrative, as it looks at ways in which narrators relate to characters in story worlds, participants in interactional worlds and wider circulating discourses (see Bamberg, 1997; De Fina, 2013; Depperman, 2013). However, we can regard positioning as a more general umbrella term that includes the strategies and mechanisms through which individuals and groups construct and convey the ways in which they regard and relate to events, discourses and people they are interacting with directly or indirectly. Positioning is often conveyed through stance taking. Indeed, as Dubois states "Stance has the power to assign value to objects of interest, to position social actors with respect to those objects, to calibrate alignment between stancetakers, and to invoke presupposed systems of sociocultural value." (2007:140). Du Bois sees stance as being expressed principally on an epistemic scale (having to do with knowledge) or on an affective scale (having to do with emotions). But the most important point that he conveys is that expressing a stance always involves not only the subject's positioning with regards to some object (be it a text, a discourse, an event or something else) but also some form of alignment or disalignment with respect to interlocutors. Indeed, as authors of utterances take stances they often position others in particular ways and recipients can also react to stances 
by producing their own stances and affiliating or disaffiliating with others. Thus, stance is interactively constructed as it has been demonstrated in different studies applying the construct to everyday interaction (see for example Goodwin 2006 and papers in Jaffe 2009). Stance taking has attracted particular attention in the study of social media environments (see for example Giaxoglou and Spilioti 2020) precisely because these digital contexts invite a high level of interactivity. As people share news and information, they position themselves while inviting others to respond. Thus, alignment and disaligment are central moves in these types of communicative environments and for this reason it is important to look at ways in which participation is organized in order to account for the interactive construction of stances and alignments.

Such organization is captured in the notion of "participation frameworks" proposed by Goffman (1981), which concerns the different roles and alignments that participants in communicative events can take in regards to each other. Goffman proposed to decompose the notion of speaker and hearer into finer categories. He distinguished the author (the agent actually responsible for an utterance), the animator (the agent giving voice to the utterance) and the principal (the agents speaking on behalf of someone). In terms of audience, he distinguished addressed from non addressed participants and discussed different roles on a scale that goes from principal addressees to overhearers. In social media for example, it is often the case that people repost or share opinions of which they are not the direct authors, but which they may present in the quality of animators or principals (by speaking on behalf of someone else). Similarly, participants that constitute the 'audiences' of texts can take up or not the role of addressees and their role can also evolve as they may at some point become main addressees in the course of the interaction. The role of audience members is particularly salient in the uptake of posts since they may intervene with different degrees of agency by taking stances on issues and aligning and disaligning with authors of posts. For this reason, uptake by other participants is an integral part of the analysis presented here since through the way they contribute to the interaction it is possible to understand how resistance is interpreted and negotiated and to discover cases in which acts of resistance are initiated by interlocutors. At the same time, it is essential to also show that resistance may emerge in different ways, for example as a result of comments and not necessarily as stemming from the individual who posts something. Let us now analyze some examples from different categories of posts as described above: reflections on political issues, the telling of stories and the relaying (through photos or other tools) of everyday events. 


\section{Example 1: Open reflections on social/political issues}

Our first example is from a post that belongs to the category of reflections on political events and figures as Mohammed here expresses an opinion on events that were reported in the local press. In April 2020 he reposts a message from a prominent member of the African community, the President of the city's "Cultural Council" in which he is tagged. The message is written in form of a letter and at the end of it presents a link to a video from one of the city's local TV channels. In the message the original author denounces attempts by the press to accuse "foreign citizens" of spreading the Covid-19 and contributing to the pandemic and advises them to stay home. The accusation is contained in the video linked below the text, which has been circulated by a local channel with the title "Palermo, [Street name]: many people on the streets who do not care about prohibitions." The video shows mostly black people out on a city street. The original posting is in French, but Mohammed publishes it in translation into Italian.

The posts says:

Quando alcuni dei nostri detrattori approfittano di questa pandemia per accusare i cittadini stranieri di essere recalcitranti di fronte al rispetto delle misure di contenimento, allora il presidente del consiglio culturale che sono, scende in campo ancora una volta per dire che si tratta semplicemente di una questione di ripresa politica in quanto il luogo che vediamo nel video si trova nella zona del mercato di [name], dove si vendono prodotti alimentari etnici.

La destra nella sua politica anti-migrante continua a puntare il dito contro la popolazione straniera ogni volta che trova un'opportunità o occasione con il solo intento di cercare voti.

NB: Considerando la sensibilità della situazione socio-politica creata dall'avvento di Covid-19, chiedo davvero ai miei fratelli di evitare il più possibile di farsi vedere fuori, vale a dire di rimanere il più possibile a casa.

Salviamo tutti la nostra bella Italia!

Io Resto a Casa.

Restiamo a Casa! 


\section{Translation}

When some of our detractors take advantage of this pandemic to accuse foreign citizens of being resistant to containment measures, then as president of the cultural council I intervene once again to say that this is a political move since the place that is shown in the video is within the area of the market of [name of the market], where ethnic products are sold. The right-wing in its anti-migrant policy continues to accuse foreign citizens every time that they have an opportunity or occasion just to look for votes.

NB: Considering the delicate socio-political situation created by the advent of Covid-19, I really ask my brothers to avoid as much as possible to be seen outside and to stay home as much as they can.

Let us save our beautiful Italy!

I stay home

Let's stay home!

As we see, here the author of the opinion is not Mohammed. He is acting as the animator of the City Council's representative. The representative takes both an epistemic and an affective stance towards the mass media that circulate news in the city. In terms of epistemic stance, he denounces the credibility of the information by pointing to the fact that the area presented in the video as crowded with "foreign citizens" is a market where "ethnic products" are sold, implying that this is the reason why most of the people appearing in the images are foreigners. Second, he expresses a moral stance of indignation against what he calls the "anti-immigrant" policy of the right-wing government. He also encourages foreign citizens to stay home but does so expressing a stance of solidarity through the expression "brothers". It can be said that his act of resistance of countering misinformation is compounded by an appeal to a specific strategy of resistance: staying home not only for personal safety but also in order to avoid becoming the target of blame. The post receives 12 reactions and 6 comments, one of which is in English and the rest in Italian.

I have designated each participant with $\mathrm{P}+$ number. I used Moh for Mohammed and AM for the President of the cultural council. Let us examine the comments:

P1: I agree with you 100 percent [in English in the original]

Moh: Dobbiamo rispettare i consigli, per il bene di tutti quanti

P2: Rispettare vuole dire salvare la nostra vita, è difficile per tutti, lo dobbiamo fare per poter fermare i corona virus 
P3: Se non sbaglio, il giorno in cui sono state fatte le riprese è il giorno in cui si è cominciato a raccogliere le autocertificazioni del comune per i buoni spesa. Il motivo per cui sono tutti fuori è che tutti cercavano posti dove potere completare la procedura, ed ovviamente la zona dove si è registrato il maggiore numero di stranieri per le strade era via [name of street]. Non è così tutti i giorni, anche se i negozi di prodotti etnici rimangono aperti. C'è una ragione specifica.

Con questo non voglio giustificare nessuno ovviamente, dobbiamo tutti essere responsabili e rimanere a casa per il bene nostro e di chi ci sta intorno.

AM: P3, grazie per l'info!

P4: Grazie mille P3!

Translation

P1: I agree with you 100 percent.

Moh.: we need to follow this advice for the good of everyone!

P2: To follow this means to save our life, it is difficult for everyone, we need to do it in order to be able to stop the corona virus

P3: If I am not mistaken the day in which this video was taken is the day in which the city council started to collect the self-certification for food stamps. The reason why everyone is out is that they all were looking for places where they could carry out the procedure, and obviously the area where the greatest number of foreign citizens was found is [name of street]. This does not happen every day. Even when the shops selling ethnic products are open. There is a specific reason. With this I do not want to justify anybody, of course, we all need to be responsible and stay home for our own good and for the good of other around us.

AM: Thank you for the information, P3

P4: Thanks a lot P3!

There are a number of things to be noted here. In this case the original act of resistance is produced by the president of the cultural council of the city as he denounces an attempt (widely present in the Italian media) to blame migrants for the spreading of Covid-19. By reposting the message Mohammed aligns with the council member and so does P1, by declaring his total agreement. In his comment, Mohammed also aligns with the author more explicitly by inviting participants to follow his advice. We see that P2 also expresses agreement with the stay at home message. But through the following exchange we see that the way resistance is expressed is also negotiated by participants. Indeed, Mohammed, P1 and P2 simply express an agreement with the stay at home message as a strategy to avoid blame 
and to some extent they implicitly accept the information presented in the video but justify the fact that "foreign citizens" are on the street as due to the presence of " ethnic markets." P3 takes a different, more radical epistemic stance with regards to the arguments presented in the video. Indeed, this participant debunks the "facts" on which it is based in a more substantial way by arguing that the foreign citizens were on the street because they were trying to get information about how to fill in forms for receiving food stamps. P3's reaction then is not only to agree to a policy of avoiding blame, but also to counteract it with alternative information. We see that through her comment she becomes the principal addressee of the community leader and another participant who thank her for having provided this piece of information. It is also important to note that $\mathrm{P} 3$ is from Palermo, therefore she may have better access to information sources than the migrants themselves.

What example 1 shows is that individuals may act as "amplifiers" of resistant messages, rather than as authors, but also that the way resistance is deployed and interpreted may evolve through collaborative work. It also shows the significance of collaboration and exchange of information between locals and migrants.

\section{Example 2: Storytelling}

As mentioned in the introduction, the telling of personal experience is another way in which Mohammed position himself vis-à-vis social issues that affect him and other migrants. In the post that I analyze below, Mohammed expresses his resistance to racism by telling a personal story about his own encounter with it and commenting on it. In the post, published in July 2020, he reproduces a Whatsapp exchange that he had with someone who openly attacked him with a racial slur. He posts a screen shot of the Whatsapp exchange prefaced with the following comment on the story:

Nella mia vita ho visto di peggio, e ho sentito di peggio. Quindi un messaggio del genere non mi fa nessun effetto. Il razzismo esiste soltanto quando ne parliamo, lei non è razzista. Non mi vuole bene è semplice. (2 emojis for laughter with a heart in the middle)

Screen shot of Whatsapp Message

P1: Insult and racial slur

Moh: Perché dici questo? 
Moh: Perché ti tratti così? Perché non è me che tratti in questo modo. Vali molto di più. Se vuoi davvero conoscermi c'è un altro modo, ti posso dare l'occasione. Io sono [name] e vengo dalla Guinea

\section{Translation}

In my life I have seen worse things, and I have heard worse things. Therefore, a message of this kind has no effect on me. Racism exists only when we talk about it, she is not racist. She does not like me it's simple.

Screen shot of Whatsapp Message

P1: Insult and racial slur

Moh: why do you say this?

Moh: Why do you treat yourself like this? Because it is not me that you are treating like that. You are worth much more. If you really want to know me, there is another way. I am [name] and I come from Guinea.

Analyzing the storytelling from the point of view of positioning is interesting because it reveals the way that Mohammed constructs his act of resistance. First, he reproduces the dialogue as it happened on Whatsapp and then he reflects on it. By presenting the dialogue he positions himself towards the characters in the storyworld: his antagonist is depicted as the producer of the insult, and therefore as the aggressor, while he is depicted as a victim but also as a victim that does not respond violently. In the open comment on the story Mohhammed positions himself towards more general societal ideologies and values. His position is that racism becomes alive when one talks about it and therefore he seems to imply that a way of resisting racism is to not elevate it to the dignity of an ideology. At the level of interactional positioning, Mohammed presents himself to other participants as a controlled person who has the ability to overcome the difficult experiences that life has thrown on his way and that is also capable of elevating himself beyond petty aggression. The message conveys resistance to racism and a strategy which involves not falling into the trap of confrontation but rather opening a dialogue with the racist person.

The post receives 66 reactions and 28 comments in Italian, Sicilian dialect and French. All comments align with Mohammed's acts of resistance against racism, but they express a variety of different stances. Some focus on expressing a stance of indignation by insulting the person who made the racist comment, but the vast 
majority of the comments praise Mohammed for his own stance of non-involvement with verbal violence or offer suggestions on how to react to these kinds of things. I provide a few examples below

P1: Futtitinni. [Sicilian]

P2: Dommage [French]

P3: Bravo frate, l'ignoranza va ignorata + two laughing emojis [ Italian]

P4: Sei un Grande e tutti noi ti vogliamo un mondo di bene. Fregatini di gente così [Italian]

P5: Beh purtroppo gente così ce ne sono tante in giro io direi di non dargli reta ... Sono più disperati di noi! [Italian]

Translation

P1: Do not pay attention. [Sicilian]

P2: What a shame [French]

P3: Well done brother, ignorance has to be ignored + two laughing emojis [Italian] P4: You are great and we all love you a lot. Don't bother with people like this [Italian]

P5: Well unfortunately there are many people like this I would say not to pay attention... They are more desperate than we are![Italian]

What this post shows once again is that acts of resistance often constitute the starting point for meaning making processes in which different members of the virtual community participate to ultimately confirm or modify interpretations and reactions. Here we see a largely shared view that Mohammed has acted correctly and that his strategy pays, but at the same time the alignment of so many friends collectively creates a stance of solidarity, which in itself can be seen as a further act of resistance. In other words, Mohammed resists racism by not engaging, and his friends also resist against racism by rallying around him and showing their appreciation for him as a person that is ethically superior. It is also interesting to note how not only local youth, but also other migrants select Italian and Sicilian as their preferred languages in the comments to this post, a choice that according to my ethnographic observation of many of the interactions surrounding other posts seem to index a sense of belonging to the local community formed by Mohammed's friends from the school. 


\section{Example 3: Resistance emerging in comments}

A third case I would like to discuss here is represented by acts of resistance that emerge in comments rather than originating in the posts published by Mohammed. This is the case with references to anti-migrant attitudes and policies by Salvini, Deputy Prime Minister of Italy and Minister of the Interior from 1 June 2018 to 5 September 2019, well known for his anti-immigrant policies. An example can be found in comments to a post published in May 2019 in which Mohammed uploads a video of himself announcing that he has got engaged with a girl. The video receives 34 reactions including emojis for laughter, love and like and 33 comments in French, Italian, English, and digital translingua. Comments include jokes and ironies, for example «Tu fais trop rire toi" +3 laughing emojis [French : you make me laugh too much], many congratulations such as "Félicitation et soit heureux" [French: congratulations, be happy]. Among them we find also two comments referring to Salvini:

Salvini vas te sécuriser petit [French]

Salvini will securitize you little one

Salvini te donne directement les papiers mes félicitations moi j’ai déjà ooooo [French ]

Salvini will give you the papers directly my congratulations I already have them ooooo

These comments take a joyous event in the life of Mohammed, his engagement, as a starting point to express their resistance to the repressive policy of the Salvini government. Indeed, the right wing in Italy, in line with many other similar parties in Europe, presented immigrants as a constant danger, criminals and people who do not belong to the country, therefore different and separated from Italians. Here the two participants use of a non-serious stance (irony) to mock prejudice is form of resistance. The irony is based on the fact that Mohammed's engagement is with an Italian girl, something that in itself would constitute a violation of the moral norms proposed by anti-immigrant movements which advocate for a total separation between Italians and immigrants. That is why the author of the first comment notes that Salvini would "securitize" his friend, thus punishing him for disregarding those norms. The second comment goes in the same direction by jokingly describing Mohammed's engagement as a move that will lead him to obtain his legal papers. 
This plays into another stereotype about migrants, that is that they use all possible means in order to become legal. The joke here is based on the paradox created by the image of Salvini himself giving the legal papers to Mohammed.

This example presents acts of resistance that emerge in a non-political context but have the effect of transforming an everyday event into an occasion for reflection on underlining issues related to the struggles of immigrant youth. It is worthwhile noting that these spontaneous acts of resistance are not rare in this corpus. Indeed, references to Salvini are made not only by Mohammed in political posts, but often by his friends in other contexts. In another example from October 2018, Mohammed reposts a video of himself in which he has been tagged by a friend that shows him participating in a lab organized for other migrants by the school. In the video he is putting some music on and moving at the rhythm of the song while the participants in the workshop are drawing. The post receives 21 reactions and 3 comments, two in French and one in Italian, reproduced below:

P1: maintenant tu es devenu musician ahahah +3 laughing emojis [French]

P2: Vrai gay [French]

P3: La pacchia continua + Laughing emoji [Italian]

\section{Translation}

P1: now you have become a musician [French]

P2: really cool [Frenach]

P3: the godsend goes on + Laughing emoji [Italian]

While the first two participants comment on Mohammed's performance, the third one uses a joking stance (marked by the the laughing emoji) to mock a famous expression repeated by Salvini in different contexts. Salvini used to say that for migrants "la pacchia è finita" (literally the "godsend" is over, meaning the party is over) to indicate his tough stance on migration. The idea that life for migrants was a "pacchia" is a common trope for right wingers who depict migrants as people who take advantage of social benefits and receive money from the state thus robbing "legal citiziens" of their money and living a life of ease and parasitism. Again, in this post, resistance is achieved through an ironic stance. P3 reverses Salvini's phrase by stating that Mohammed's engagement shows that the party is not over but actually continues. 
Like in the previous example, resistance here implies reinterpretations of everyday life events in light of their social, ethical or political meaning vis-à-vis stereotypical, anti-immigrant discourses. These kinds of reinterpretations can only be understood and only make sense with reference to those discourses. For this reason, I am going to argue here that other less directly oppositional posts can also be interpreted as everyday acts of resistance.

\section{Example 4: Implied resistance}

My last example refers to an instanceof the ethical positioning posts that I described in the introduction. In October 2018 Mohammed posted a photo of himself with two friends (also migrant youth) tagging one of his friends, that we will call Alain.

The photo shows Mohammed Alain and another friend. One of them smiling and with his fingers touching his forehead in a military salute, the other smiling while doing a horn sign with his fingers, and the third one with thumbs down (both signs of approval in this youth's culture). All of them wear a t-shirt with the name of the school. The following text accompanies the picture:

(4)

Il nostro amore è la nostra casa. I nostri piedi possono andarsene ma il cuore mai. Cittadini del mondo.

Translation

Our love is our home. Our feet can go away but never our heart.

Citizens of the world.

The post receives 108 reactions (emojis for likes, hearts, and so forth) and 11 comments in French, Italian and digital translingua. The comments all express a positive, affectionate stance and alignment with Mohammed. See examples below

P1: Cool mon frère [translingua with French]:

P2: Grandi!! [italian]

P3: Que dieu vous benisse! [French] 
Translation

P1: cool my friend [Franch]

P2: great !! [Italian]

P3: god bless you! [French]

Alain comments in Italian by saying "siamo il mondo fra". I think he means "we are the world, brother." Mohammed's photo presents a portrait of young people of foreign origins, in particular of three men from Africa looking happy and giving a positive message not only about their friendship but also about their place in the world. With this image through which Mohammed expresses a proud stance, he positions himself and his friends in stark contrast with mainstream views of immigrants, especially African immigrants, that are either depicted as criminals or as desperate individuals crowding boats in the Mediterranean bound to European ports. As Giubilaro (2018) notes, discourses on migration in Italy show a kind of alternation between attitudes focused on pity and attitudes underlining fear and rejection. In any case, migrants are just spectacles of commiseration or surveillance, but never agents and people in their own right. In this way, Mohammed's post can be seen as an implicit act of resistance to being boxed in the category of 'migrant' and an affirmation of a completely different self-presentation. He underscores a positive view of himself and youth like him as citizens of the world, people who speak different languages and are at ease in different countries and cultures. Like in previous posts, his friends accomplish their own act of resistance by rallying around him.

\section{DISCUSSION AND CONCLUSIONS}

In this paper I have analyzed acts of resistance by migrant youth and their friends. I have focused on a digital environment in order to highlight two important aspects of this construct: first that resistance does not necessarily flourish in political environments but can emerge in everyday communication and secondly that it is often the outcome of collaboration and negotiation. I have defined resistance here as encompassing opposition to ideas, social conditions, institutional actions and processes that result or may result in discrimination or stereotyping of migrants. I have shown that these acts can be initiated by Mohammed consciously, for example through posting or reproducing opinions about social and political processes that affect migrants or indirectly, through positive self-presentations, but can also be initiated by other friends writing on his wall. These moves can have different 
developments and generate forms of uptake which may change the way resistance is understood or practiced, like in the case of Mohammed's reaction to accusations against "foreign citizens" spreading the Co-vid. We saw that in the exchange on that post another participant pointed to the need to debunk false information instead of simply complying with the stay at home requirements.

We also saw resistance acts emerge in relation to everyday events and situations within interactions that are not focused on political or social issues. This was the case with comments on a post relating to Mohammed's engagement or to his participation in a workshop at school. These comments presented interpretations of everyday events in light of the framing that right wing discourse makes of the social behavior of migrants. These comments also illustrate how acts of resistance can be embedded in interaction and can be originated by any participant.

The analysis also illustrates the multiple strategies that participants in digital communication use to express resistance: from the telling of personal stories, to the entextualization of materials from different sources (for example other texts, photos or video), to the interdiscursive reprise of common tropes.

But what makes resistance particularly effective is the sharing that takes place in digital environments which allows individuals to find support and to discuss ways to fight against discrimination. Indeed, another important point that I have made is that migrants are not isolated human beings and they are not, particularly in our age and time, boxed into ethnic communities. They are individuals connected with many different networks. Importantly, some of these networks include members of local communities with whom they have significant exchanges that affect both sides. In this case we have seen for example not only that members of local communities may add important information available to them in order to contribute to the development of resistance strategies, but also that their participation in online communities generates the kind of support that in itself constitutes a new act of resistance to discrimination and isolation.

\section{Acknowledgement}

I want to warmly thank two anonymous reviewers for their constructive feedback on my paper, which helped me improve its quality. All remaining problems and issues are entirely my responsibility. 


\section{REFERENCES}

ARNAUT, K., ET AL. (eds.) (2015). Language and superdiversity. London: Routledge.

APPADURAI. A. (1996). Modernity at large: Cultural dimensions of globalization Minneapolis: University of Minnesota Press.

BALABANOVA, E \& TRANDAFOIU, R. (2020). Discourse and resistance in the context of the erosion of liberal norms. Journal of Language and Politics, n. 19 (3), p.379-390.

BHABA, H.K. (1994). The location of culture. London: Routledge.

BAMBERG, M. (1997). Positioning between structure and performance. Journal of Narrative and Life History, n.7, vs.1-4, p. 335-342.

BLOMMAERT, J., \& RAMPTON, B. (2011). Language and superdiversity. Diversities, v. 1, n.33. Available at: http://www.unesco.org/shs/diversities/vol13/issue2/art1. Accessed on August 19, 2020.

BUTLER, J. (2015). Notes towards a performative theory of assembly. Cambridge, Mass.: Harvard University Press.

CASTELLS, M. (2000). The rise of the network society. Oxford, Blackwell.

CHIBUWE, A., \& UREKE, O. (2016). 'Political gladiators' on Facebook in Zimbabwe: A discursive analysis of intra-Zimbabwe African National Union-PF cyber wars; Baba Jukwa versus Amai Jukwa. Media, Culture and Society, v. 8, n. 38, p. 1247-1260.

DU BOIS, J. (2007). The stance triangle. In Englebretson, R. (ed.), Stancetaking in discourse, Amsterdam: John Benjamins, p. 139-82.

CHILUWA, I. (2012). Social media networks and the discourse of resistance: A sociolinguistic CDA of Biafra online discourses. Discourse \& Society, v. 3, n. 23, p. 217-244.

COLOMBO, F. (2019). Minori non accompagnati in Italia: Profili,politiche e leggi. Lenius, 2 August, 2019. Available at: https://www.lenius.it/minori-stranieri-nonaccompagnati-in-italia/ Accessed 30 August, 2020.

CREESE, A. \& BLACKLEDGE, A. (eds.) (2018). The Routledge bandbook of language and superdiversity. New York: Routledge. 
DAVIES, C., \& HARRÉ, R. (1990). Positioning The discursive construction of selves. Journal for the Theory of Social Behavior, n. 20, pp. 43-63.

DE CERTEAU, M. (1984). The Practice of everyday life. Translation by Steven Rendall, University of California Press, Berkeley.

DE FINA, A. (2011). Discourse and identity. In T.A. Van Dijk (ed.) Discourse studies: A multidisciplinary introduction. London: Sage, p. 263-282.

DE FINA, A. (2013) Positioning level 3: Connecting local identity displays to macro social processes. Narrative Inquiry, v. 23, n. 1, p. 40-61(22).

DE FINA, A. (2015) Narrative and identities. In De Fina, A. \& Georgakopoulou, A.(eds.), Handbook of narrative analysis. Malden, MA: Wiley, p. 369-387.

DE FINA, A., PATERNOSTRO, G. \& AMORUSO, M. (2020a). Learning how to tell, learning how to ask: Reciprocity and storytelling as a sommunity process. Applied Linguistics, v. 41, n. 3, p. 352-369.

DE FINA, A., PATERNOSTRO, G. \& AMORUSO, M. (2020b). Odysseus the traveler: Appropriation of a chronotopes in a community of practice. Language \& Communication, v. 70, p. $71-81$.

DE FINA, A., IKIZOGLU, D. \& WEGNER, J. (eds.) (2017) Diversity and superdiversity. Sociocultural linguistic perspectives. Washington DC : Georgetown University Press.

DEPPERMAN, A. (2013). Positioning in narrative interaction. Narrative Inquiry, v. 23, n.1, p. $1-15$.

ELYACHAR, J. \& WINEGAR, J. (eds.) (2012). "Revolution and counter-revolution in Egypt a year after January 25th." Fieldsights_-Hot Spots, Cultural Antbropology Online. Available at: http://www. culanth.org/fieldsights/208-revolution-and-counterrevolution-in-egypt-a-year-after-january25th. Accessed on 25 July, 2020.

FOUCAULT, M. (1978). The History of sexuality. Translated by Robert Hurley New York: Random House, 1976.

FOUCAULT, M. (2007). Security, territory, population. Lectures at the Collège de France, 1977-78. Translated by Graham Burchell. New York: Palgrave MacMillan.

GIAXOGLU, K. \& SPILIOTI, T. (2020). The shared story of \#JeSuisAylan on Twitter: story participation and stancetaking in visual small stories. Pragmatics, v. 30, n. 2, p. 277-302. 
GIUBILARO, C. (2018) (Un) framing Lampedusa: Regimes of visibility and the politics of affect in Italian media representations. In, Proglio, G. and Odasso, L. (eds.) Border Lampedusa. Cham: Palgrave Macmillan, p. 103-118.

GOFFMAN, E. (1981). Forms of talk. Philadelphia: University of Pennsylvania Press.

GOODWIN, M.H. (2006). The bidden life of girls: Games of stance, status, and exclusion. Malden, MA: Blackwell.

HALL, S. AND JEFFERSON, T. (eds.) (1976). Resistance through rituals. London: Routledge.

HINE, C. (2015). Ethnography for the Internet. London: Bloomsbury.

HICKEL, J. (2012). Liberalism and the Politics of Occupy Wall Street. Antbropology of this Century, no. 4. Available at: http://aotcpress.com/articles/liberalism-politicsoccupywall-street/. Accessed 22 June, 2020.

HOLLANDER, J. A.\& EINWOHNER, R. L. (2004). Conceptualizing Resistance. Sociological Forum, v.19, n. 4, p. 533-554.

IDLE, N. \& NUNNS, A. (eds.) (2011) Tweets from Tabrir: Egypt's revolution as it unfolded in the words of the people who made it. New York: Or Books

JACQUEMET, M. (2019). Beyond the speech community: On belonging to a multilingual, diasporic, and digital social network. Language \& Communication, n. 68, p. 45-56

JAFFE, A. (ed.) (2009). Stance: Sociolinguistic perspectives. Oxford: Oxford University Press.

LAZAR, M. (2017). Homonationalist discourse as a politics of pragmatic resistance in Singapore's Pink Dot movement: Towards a southern praxis. Journal of Sociolinguistics, v. 21, n. 3, p. $420-441$

LI, WEI (2018). Translanguaging as a practical theory of language. Applied Linguistics- v., 00, n. $0,1-23$.

MARTIN ROJO, L. (2014). Occupy: The spatial dynamics of discourse in global protest movements. Journal of Language and Politics, v.13, n. 4, p.583-598.

MERRIAM/WEBSTER DICTIONARY. Available at: https://www.merriam-webster.com/ dictionary/resistance. Accessed 10 August, 2020. 
MINISTERO DEL LAVORO E DELLE POLITICHE SOCIALI (2018) Report Mensile Minori Stranieri Non Accompagnati (Msna) in Italia Dati al 28 febbraio 2018. Available from https://www.lavoro.gov.it/temi-e-priorita/immigrazione/focus-on/ minori-stranieri/Documents/Report-MSNA-mese-febbraio-2018-29032018.pdf, retrieved 31 August, 2020.

MPOFU, P. (2018). Linguistic disenfranchisement, minority resistance and language revitalisation: The contributions of ethnolinguistic online communities in Zimbabwe. Cogent Arts \& Humanities, v. 5, n.1. Available from https://www.tandfonline.com/doi/fu $11 / 10.1080 / 23311983.2018 .1551764$

PAPADOPOULOS, D. \& TSIANOS, V.S. (2013). After citizenship: autonomy of migration, organisational ontology and mobile commons. Citizenship Studies, v. 17, n. 2, p. $178-196$.

PENNYCOOK, A. \& OTSUJI, E. (2018). Metrolingualism. Abingdon: Routledge.

RAMPTON, B. (1996) Youth, race, and resistance: A sociolinguistic perspective. Linguistics and Education, v.8, n.2, p. 159-173.

RAZSA, M. \& KURNIK, A. (2012). The Occupy movement in Žižek's hometown: Direct democracy and a politics of becoming. American Ethnologist, v. 39, n.2, p. 238-258.

SELONI, L. \& SARFATI, Y. (2017). Linguistic landscape of Gezi Park protests in Turkey: A discourse analysis of graffiti. Journal of Language and Politics, v. 16, n. 6, p.782-808.

SINATORA, F. L. (2019). Language, identity, and syrian political activism on social media. New York: Routledge.

THEODOSSOPOULOS, D. (2013). Infuriated with the infuriated? Blaming tactics and discontent about the Greek financial crisis. Current Antbropology, v. 54, n. 2, p. 200-221.

URLA, J. \& HELEPOLOLEI, J. (2014). The ethnography of resistance then and now. History and Antbropology v. 25, p. 431-451.

VERTOVEC, S. (2007). Super-diversity and its implications, Ethnic and Racial Studies, v. 30, n.6, 1024-1054.

VITAK, J. (2012). The impact of context collapse and privacy on social network site disclosures. Journal of Broadcasting and Electronic Media, v. 56, n. 4, p. 451-470. 
ZHU HUA, LI WEI \& LYONS, A. (2017). Polish shop(ping) as translanguaging space. Social Semiotics, v.27, n.4, 411-433.

Recebido: 22/9/2020

Aceito: 17/11/2020

Publicado: 23/11/2020 